\title{
Infectious Bronchitis Vaccination Protocols for Laying Hens
}

\author{
A. Sulaiman ${ }^{\mathrm{a}, *}$ \& J. R. Roberts ${ }^{\mathrm{b}}$ \\ aAnimal Production Study Program, Faculty of Agriculture, Lambung Mangkurat University \\ Jln. A. Yani KM 36, Banjarbaru 70714, Indonesia \\ ${ }^{\mathrm{b}}$ Animal Science, School of Rural Science and Agriculture, The University of New England \\ Armidale, NSW 2351 \\ (Received 06-10-2010; accepted 22-07-2011)
}

\begin{abstract}
ABSTRAK
Penelitian ini bertujuan untuk mengkaji pengaruh pengaturan vaksinasi infectious bronchitis (IB) terhadap produksi telur, kualitas telur, dan tingkat antibodi IB. Perlakuan vaksinasi IB yang berbeda (kontrol, VicS mata, VicS spray, VicS air, $A_{3}$ mata, $A_{3}$ spray, and $A_{3}$ air) diberikan pada ayam Isa Brown berumur satu hari. Setengah dari jumlah ayam divaksinasi kembali secara rutin pada umur 22, 30, 38, 46 and 54 minggu, sedangkan sisanya tidak divaksinasi. Hasil menunjukkan bahwa perlakuan vaksinasi memiliki pengaruh nyata terhadap produksi telur dan kualitas telur (berat telur, reflekitivitas cangkang, kekuatan cangkang, ketebalan cangkang, berat albumen, Haugh Units), dan tingkat antibodi IB, tetapi tidak berpengaruh terhadap persentase cangkang dan warna kuning telur. Berat telur dan reflektivitas cangkang kurang baik pada kontrol. Sebaliknya, kekuatan dan ketebalan cangkang pada kelompok yang diberi vaksin A3 pada air minum memiliki nilai tertinggi. Revaksinasi secara reguler memiliki efek yang mengganggu produksi dan kualitas telur, tetapi tidak berpengaruh nyata terhadap tingkat antibodi IB. Kesimpulan penelitian ini bahwa revaksinasi virus IB secara reguler hanya memberikan keuntungan yang sedikit, jika ayam telah memperoleh vaksinasi awal yang tepat.
\end{abstract}

Kata kunci: infectious bronchitis, vaksinasi, revaksinasi, ayam petelur

\section{ABSTRACT}

A research was conducted to investigate the effects of vaccination protocols for Infectious Bronchitis (IB) on egg production, egg quality, and IB antibody titres of laying hens. Different initial vaccination (Control, VicS eye, VicS spray, VicS water, A3 eye, A3 spray, and A3 water) for IB were administered to day-old Isa Brown hens. Half the hens were revaccinated regularly during lay whereas the other hens were not vaccinated. Results showed that initial vaccination treatment had significant effects on hen day egg production and egg quality of egg weight, shell reflectivity, shell breaking strength, shell thickness, albumen height, Haugh Units, and IB antibody titre levels, but had no effect on percentage of shell and yolk colour. Egg weight and shell reflectivity were less favourable in the control hens. In contrast, shell breaking strength and shell thickness were highest for the group that initially received A3 vaccine in water. However, regular revaccination had some deleterious effects on egg production and egg quality. There were no significant effects of revaccination on IB antibody titres. It is concluded that there was little advantage in regularly revaccinating laying hens for IB virus, since they had received appropriate initial vaccination.

Key words: infectious bronchitis, vaccination, revaccination, laying hens

\section{INTRODUCTION}

Infectious bronchitis (IB) is a highly infectious and contagious respiratory virus disease which has been widespread and identified all over the world. The infec-

\footnotetext{
*Corresponding author:

e-mail: asulaima@unlam.ac.id
}

tion has a great economical effect on the layer industry, because it affects on egg production. Besides respiratory lesions, early exposure to IB virus causes extensive damage to wide range of various epithelial surfaces of the body both in layers (Cavanagh, 2003). Chousalkar et al. (2007) reported IB virus affected on Harderian gland, tracheal mucosa, kidney, and region of oviduct such as the magnum, tubular shell gland, and shell gland pouch of laying hens. It is associated with nephritis and 
respiratory distress in broilers and with the so-called "false layer syndrome" and drops in egg production in breeders and layers. It is therefore causing major economic problems in IB-vaccinated flocks (de Wit et al., 2011). Butcher \& Miles (2001) mentioned that for laying hens IB not only affects egg production but also egg shell and internal egg quality.

The syndrome may cause partial or complete failure of the oviduct to develop, and in laying period, hens will not ovulate normally. Poor egg specific gravity, reduced shell thickness, misshapen eggs, pale shell pigmentation, watery albumen that leads to greatly reduced Haugh Unit (HU) values are a reflection of dysfunctional or damaged oviducts (Butcher \& Miles, 2001). Therefore, it is relevant to investigate the suitability of the current vaccines in protecting birds in the field.

Since there is no appropriate drug therapy for controlling this disease, increasing the resistance of birds by vaccination is still the cornerstone of strategy for protecting chickens from IBV infection (Lister, 2001). Although no homologous vaccine was available until very recently, some success is reported in controlling its effects using currently available IB vaccines (de Wit et al., 2011). Various IB virus serotypes are used as commercial bronchitis vaccines worldwide including Massachusetts, Connecticut, Holland, Arkansas, Florida and JMK. Both live and inactivated virus vaccines are used in broilers and for the initial vaccination of breeders and layers (Cavanagh \& Gelb Jr., 2008).

The most common strains of IB virus vaccine used by the egg industry were Webster's VicS (Fort Dodge) and A3 (Fort Dodge). Some producers use only one strain (usually VicS) whereas others alternate the two strains during the rearing phase. Routes of vaccine administration vary, with coarse spray at the hatchery, and either coarse spray or in water vaccination for subsequent vaccinations, being the norm. Some producers do not revaccinate for IB once the birds have come into lay. However, increasingly, poultry veterinarians are recommending regular revaccination, usually every 8 weeks throughout lay. Results from a previous experiment, using Webster's VicS IB vaccine strain with ISA brown cockerels, indicated that vaccination at either day-old or two weeks of age, by eye drop, coarse spray or water vaccination, protected birds against the effects of exposure to T strain IB virus.

The objectives of this experiment were to determine the effects of different initial vaccination protocols (different virus strains of vaccine and routes of vaccine administration) for IB and regular revaccination every 8 weeks during lay, as compared with no revaccination beyond 14 weeks of age on hen day egg production, egg quality and IB antibody titres of ISA Brown laying hens.

\section{MATERIALS AND METHODS}

\section{Chickens and Management}

Day-old-ISA Brown layers (623 birds) were transferred to isolation pens. The birds were reared according to standard commercial practice. Seven (7) isolation floor sheds $\left(2 \times 3 \mathrm{~m}^{2}\right)$ were used. After being reared in isolation pens for 15 weeks, all birds were transferred to two poultry isolation sheds equipped with 3-bird commercial-style cages. Each cage had one feeder and at least two accessible drinking nipples. The birds were supplied with feed and drinking water ad lib. A pre-layer diet (pullet grower with added calcium) was fed until birds had reached 5\% production, after which birds received a standard commercial layer mash. Natural light was applied until birds had reached 5\% lay or 18 weeks of age, after which birds received 14 hours light ( 6 am to $8 \mathrm{pm})$. The light phase was increased by 30 minutes per week. Clinical signs and mortality were recorded if observed and all mortalities autopsied.

\section{Experimental Design and Measurements}

There were seven initial experimental groups set up at day-old, each of 89 birds: control (no vaccination), VicS eye (VicS vaccine by eye drop at day-old), VicS spray (VicS by coarse spray at day-old), VicS water (VicS in water at day-old), A3 eye (A3 vaccine strain by eye drop at day-old), A3 spray (A3 by coarse spray at day-old), A3 water (A3 in water at day-old). The Control group remained unvaccinated. At 14 weeks of age, all birds (including the control birds which had not been vaccinated previously) were revaccinated with VicS vaccine strain by eye drop. At 15 weeks of age, all birds were transferred to the two poultry isolation sheds. One-half of the birds from each treatment group were allocated to each shed, 2 birds per cage (a total of 14 groups). The birds in one shed (seven groups) were revaccinated every 8 weeks with VicS vaccine strain by coarse spray, whereas the birds in the other shed (the other seven groups) were not revaccinated beyond 14 weeks of age. For all vaccinated groups, the vaccines used were Webster's VicS (Fort Dodge) and $\mathrm{A}_{3}$ (Fort Dodge) strains of IB virus. For regular revaccination, VicS vaccine strain was used and administered by coarse spray. Revaccination of the regularly revaccinated groups was conducted at 22, 30, 38, 46, and 54 weeks of age.

Egg production, average egg weight and the external appearance of the eggs were recorded daily. Percentages of egg production were calculated as henday production. On the day of lay, 30 eggs from each treatment group were weighed using an O'haus Balance. Every 4 weeks, 21 eggs from each initial vaccination treatment group from each shed were collected for egg and eggshell quality measurements. Shell breaking strength (Newton), shell reflectivity (\%), egg weight (g), albumen height (mm), Haugh Units (HU), yolk colour (Roche score), percentage shell (shell weight/egg weight, \%) (using TSS egg analyser) and shell thickness $(\mu \mathrm{m})$ (using a digital micrometer) were measured. Measurements were conducted after all eggs were stabilized in the cool room for 24 hours and were determined at 20, 24, 28, 32, 36, 40, 44, 48, 52 and 56 weeks of age. Heparinised blood samples were centrifuged in a Hearaeus Christ centrifuge at 3000 RPM for 10 minutes to separate the blood plasma, and the blood plasma was stored frozen at $-20{ }^{\circ} \mathrm{C}$ for before analysis. IB antibody titres were measured in samples of plasma using a Flock 
Check Infectious Bronchitis Virus Antibody Test Kit (IDEXX Laboratories).

\section{Statistical Analysis}

Analysis of variance was used to test the effect of initial vaccination treatment and regular revaccination on each measured parameter. Fisher's protected LSD was utilized to separate means when significant effects were observed. Statements of statistical significance were based on $\mathrm{P}<0.05$ unless otherwise indicated.

\section{RESULTS AND DISCUSSION}

\section{Hen-day Egg Production}

Initial vaccination treatment had significant effect on hen-day egg production from 20 to 56 weeks (Table 1). Production was slightly lower for the control and A3 course spray initial vaccination treatment groups. There was effect of regular revaccination on hen-day egg pro- duction between 20 and 56 weeks of age, with the egg production of regularly revaccinated birds being lower than those without revaccinated (Table 2 and Figure 1). Egg production during this period averaged 88.1 eggs/100 hens/day in the birds that were not revaccinated and 86.6 eggs/100 hens/day in the birds that were revaccinated regularly every 8 weeks from 22 weeks to 54 weeks. Some researchers reported that applying live IB vaccines in flocks approaching peak production may produce a $10 \%$ fall in egg production which usually remained depressed for about three weeks. Whatever live vaccine is used, the application is a very critical step. IBV virus is a sensitive virus that can be inactivated easily (Cavanagh \& Gelb, 2008), which may result in inadequate efficacy of the vaccination under field conditions (Jackwood et al., 2009; de Wit et al., 2010).

The major goal of a vaccination program is to prevent disease and economic losses associated with infection by disease agents. The vaccine may be applied by eye drop or nasal drop, spray or drinking water routes and it is essential that a high percentage of the birds

Tabel 1. Means of hen day egg production and egg qualities at 20-56 weeks of laying hens treated by initial vaccination

\begin{tabular}{|c|c|c|c|c|c|c|c|c|c|}
\hline Group & $\begin{array}{l}\text { HD egg } \\
\text { production } \\
\quad(\%)\end{array}$ & $\begin{array}{c}\text { Egg } \\
\text { weight } \\
\text { (g) }\end{array}$ & $\begin{array}{c}\text { Shell } \\
\text { reflectivity } \\
(\%)\end{array}$ & $\begin{array}{l}\text { Shell break- } \\
\text { ing strength } \\
\text { (Newton) }\end{array}$ & $\begin{array}{c}\text { Percentage } \\
\text { shell } \\
(\%)\end{array}$ & $\begin{array}{l}\text { Shell thick- } \\
\text { ness } \\
(\mu \mathrm{m})\end{array}$ & $\begin{array}{c}\text { Albumen } \\
\text { height } \\
(\mathrm{mm})\end{array}$ & $\begin{array}{l}\text { Haugh } \\
\text { Units } \\
\text { (HU) }\end{array}$ & $\begin{array}{l}\text { Yolk colour } \\
\text { (Roche } \\
\text { score) }\end{array}$ \\
\hline Control & $85.1 \pm 0.80^{\mathrm{b}}$ & $56.8 \pm 0.30^{\mathrm{b}}$ & $34.2 \pm 0.30^{\mathrm{a}}$ & $42.2 \pm 0.40^{\mathrm{ab}}$ & $10.10 \pm 0.05$ & $432.8 \pm 1.70^{b}$ & $7.65 \pm 0.07^{a}$ & $87.0 \pm 0.40^{\mathrm{a}}$ & $11.21 \pm 0.10$ \\
\hline $\begin{array}{l}\text { VicS, eyedrop at } \\
\text { day-old }\end{array}$ & $87.5 \pm 0.80^{\mathrm{a}}$ & $60.1 \pm 0.40^{\mathrm{a}}$ & $33.7 \pm 0.20^{\mathrm{ab}}$ & $42.1 \pm 0.40^{\mathrm{b}}$ & $10.07 \pm 0.05$ & $431.2 \pm 1.70^{b}$ & $7.52 \pm 0.07^{\mathrm{ab}}$ & $85.8 \pm 0.50^{\mathrm{b}}$ & $11.25 \pm 0.10$ \\
\hline $\begin{array}{l}\text { VicS, coarse } \\
\text { spray at day-old }\end{array}$ & $88.5 \pm 0.70^{a}$ & $60.1 \pm 0.40^{\mathrm{a}}$ & $34.2 \pm 0.30^{\mathrm{a}}$ & $41.9 \pm 0.40^{\mathrm{bc}}$ & $10.07 \pm 0.05$ & $430.8 \pm 1.60^{b}$ & $7.47 \pm 0.06^{\mathrm{b}}$ & $85.5 \pm 0.50^{\mathrm{b}}$ & $11.24 \pm 0.10$ \\
\hline $\begin{array}{l}\text { VicS, in water at } \\
\text { day-old }\end{array}$ & $87.8 \pm 0.70^{a}$ & $59.9 \pm 0.30^{\mathrm{a}}$ & $33.3 \pm 0.20^{\mathrm{b}}$ & $41.4 \pm 0.40^{\mathrm{bc}}$ & $10.06 \pm 0.04$ & $432.9 \pm 1.50^{\mathrm{b}}$ & $7.29 \pm 0.07^{\mathrm{cd}}$ & $84.4 \pm 0.50^{c}$ & $11.23 \pm 0.10$ \\
\hline $\begin{array}{l}\text { A3, eyedrop at } \\
\text { day-old }\end{array}$ & $87.7 \pm 0.80^{a}$ & $60.3 \pm 0.40^{\mathrm{a}}$ & $32.5 \pm 0.30^{c}$ & $40.9 \pm 0.40^{c}$ & $10.03 \pm 0.05$ & $431.3 \pm 1.60^{b}$ & $7.41 \pm 0.06^{\mathrm{bc}}$ & $85.0 \pm 0.40^{\mathrm{bc}}$ & $11.32 \pm 0.10$ \\
\hline $\begin{array}{l}\text { A3, coarse spray } \\
\text { at day-old }\end{array}$ & $86.0 \pm 0.80^{b}$ & $60.3 \pm 0.30^{\mathrm{a}}$ & $33.1 \pm 0.30^{b c}$ & $41.4 \pm 0.40^{\mathrm{bc}}$ & $10.02 \pm 0.05$ & $433.1 \pm 1.80^{b}$ & $7.23 \pm 0.06^{\mathrm{d}}$ & $84.1 \pm 0.40^{c}$ & $11.21 \pm 0.10$ \\
\hline $\begin{array}{l}\text { A3, in water at } \\
\text { day-old }\end{array}$ & $88.6 \pm 0.70^{\mathrm{a}}$ & $60.2 \pm 0.30^{\mathrm{a}}$ & $33.2 \pm 0.30^{\mathrm{b}}$ & $43.2 \pm 0.40^{\mathrm{a}}$ & $10.20 \pm 0.05$ & $438.2 \pm 1.50^{\mathrm{a}}$ & $6.94 \pm 0.06^{\mathrm{e}}$ & $82.3 \pm 0.40^{\mathrm{d}}$ & $11.14 \pm 0.10$ \\
\hline
\end{tabular}

Note: Means in the same column with different superscript differ significantly $(\mathrm{P}<0.05)$.

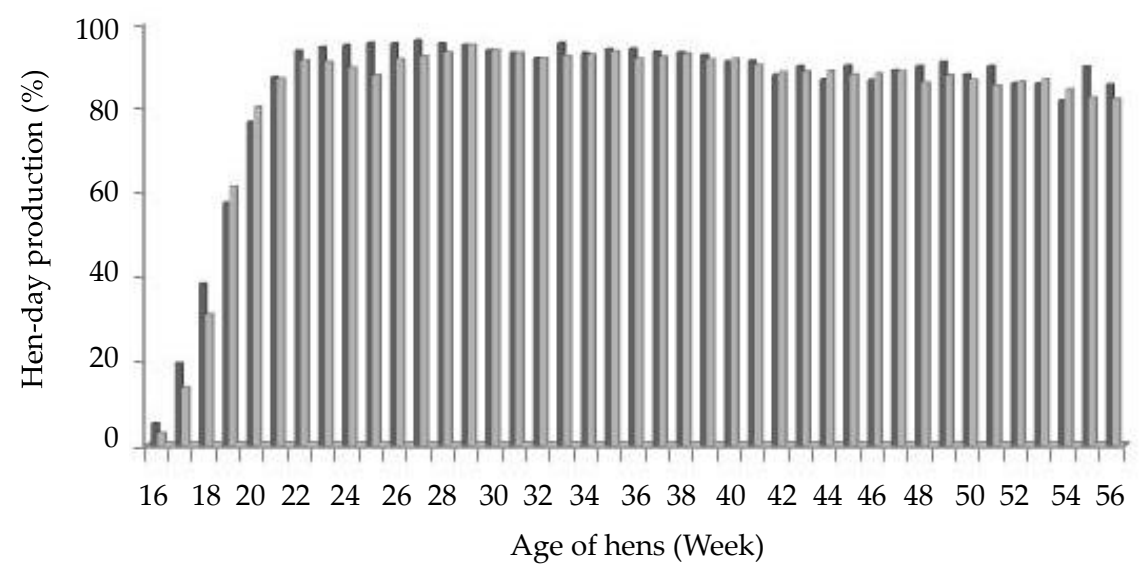

Figure 1. Production (eggs/100 hens/day) from 16 to 56 weeks of age in revaccinated hens ( $\square$ ) regularly every 8 weeks during lay or not revaccinated $(\square)$ 
receive a required dose of the vaccine in the right tissue (Cook et al., 2008). Initial vaccination treatment of IB had a number of effects on the subsequent performance of the flock, during the laying phase. The treatment given to the control group, which was no vaccination until VicS vaccine strain was administered at 14 weeks of age, had a number negative effects on the birds during lay. Production was lower for the control birds at 20-56 weeks than for the other groups except the A3 coarse spray group.

Table 2. Hen day production and egg qualities of laying hens due to revaccinated regularly or not revaccinated during lay

\begin{tabular}{lcc}
\hline \multicolumn{1}{c}{$\begin{array}{c}\text { Egg protein and } \\
\text { egg quality }\end{array}$} & Revaccinated & $\begin{array}{c}\text { Not } \\
\text { revaccinated }\end{array}$ \\
\hline $\begin{array}{l}\text { Hen day egg produc- } \\
\text { tion (\%) }\end{array}$ & $86.60 \pm 0.40^{\mathrm{b}}$ & $88.10 \pm 0.40^{\mathrm{a}}$ \\
Egg weight (g) & $60.40 \pm 0.20^{\mathrm{a}}$ & $59.40 \pm 0.20^{\mathrm{b}}$ \\
Shell reflectivity (\%) & $33.40 \pm 0.10$ & $33.40 \pm 0.01$ \\
Shell breaking & $41.20 \pm 0.20^{\mathrm{b}}$ & $42.50 \pm 0.20^{\mathrm{a}}$ \\
strength (Newton) & & \\
Percentage shell (\%) & $9.98 \pm 0.02^{\mathrm{b}}$ & $10.18 \pm 0.03^{\mathrm{a}}$ \\
Shell thickness ( $\mu \mathrm{m})$ & $430.40 \pm 0.90^{\mathrm{b}}$ & $435.30 \pm 0.90^{\mathrm{a}}$ \\
Albumen height (mm) & $7.34 \pm 0.04$ & $7.38 \pm 0.03$ \\
Haugh Units (HU) & $84.50 \pm 0.30^{\mathrm{b}}$ & $85.20 \pm 0.20^{\mathrm{a}}$ \\
Yolk colour (Roche & $11.24 \pm 0.03$ & $11.22 \pm 0.03$ \\
score) & & \\
\hline
\end{tabular}

Note: Means in the same row with different superscript differ significantly $(\mathrm{P}<0.05)$

\section{Egg and Egg Quality}

Egg weight was lower for the initial control vaccination group (birds not vaccinated at all until 14 weeks of age) than for all other treatments (Table 1). Egg weight was higher overall in the birds that were revaccinated regularly than those without revaccinated beyond 14 weeks of age (Table 2). There were significant differences among initial vaccination treatments on shell reflectivity, with shell colour being lightest for the control and VicS groups (Table 1). The groups vaccinated initially with A3 had generally darker shells. Shell colour was not affected by regular vaccination (Table 2 ).

Initial vaccination treatment group had a significant effect on shell breaking strength. There was a significant effect of regular revaccination with breaking strength being slightly higher for the eggs produced by the birds that were not revaccinated regularly (Table 2). Animal received eyedrop vaccine and water had a lower shell breaking compared to that of the other groups.

There was a significant effect of initial vaccination treatment on shell thickness (Table 1). Shell thickness was higher in the group that received A3 in water initially than for all other groups. There was a significant effect of regular revaccination on shell thickness with shell thickness being 5 microns greater for the birds that were not revaccinated regularly (Table 2 ). The birds that were revaccinated regularly during lay had thinner shells in every initial vaccination treatment except for VicS eye drop and A3 coarse spray group. A3 in water and not revaccinated was the thickest and A3 eye drop and revaccinated regularly the thinnest. There was significant difference between initial vaccination treatment groups on albumen height (Tables 1), with albumen quality being highest for the control and lowest for the A3 water group. However, there was no significant difference in albumen quality between birds that were regularly revaccinated during lay, and those that were not (Table 2).

There was a significant difference among initial vaccination treatment groups for Haugh Units (Table 1), with Haugh Units being highest for the control and lowest for the A3 water group. There was a significant effect of regular revaccination for Haugh Units, being lower for those that were revaccinated regularly during lay than those that were not. The birds that were revaccinated regularly during lay had lower Haugh Units in every initial vaccination treatment except for VicS coarse spray and A3 in water groups. However, there was no significant effect of initial vaccination treatment or regular revaccination during lay on percentage yolk colour. All yolk colour scores were at optimal levels, by egg commercial standards.

Initial vaccination at day-old with A3 strain IB virus resulted in both advantages and disadvantages during lay. Shell colour (as shell reflectivity) was darker in the A3 groups than for the control and VicS groups. Shell thickness was highest in the A3 water group. Effects on shell breaking strength were variable, with the A3 water group having the highest shell breaking strength but the A3 eye group having the lowest. However, albumen quality was lowest for the A3 water group.

Regular revaccination during lay (at 22, 30, 38, 46 , and 54 weeks of age) had no overall effect on shell reflectivity (shell colour), albumen height, and yolk colour. However, in general, egg production, eggshell quality (shell breaking strength, percentage shell, shell thickness), and egg internal quality (Haugh Units) were lower in the birds that were revaccinated regularly during lay. The negative effects of regular revaccination are most likely the result of the response of the birds to exposure to IB virus, even though as a vaccine strain. Furthermore, the negative effects of regular revaccination on egg and eggshell quality may indicate a negative effect of IB vaccine on the oviduct agrees with Cavanagh (2003) and Choulsalkar et al. (2007). Roberts (2004) reviewed factors that affect egg shell quality and egg internal quality including: the strain and age of hen, production system, nutrition, induced moult, storage, stress, and diseases. Infectious bronchitis has been reported to cause egg shells to be paler in colour and sometimes wrinkled in appearance.

The results above suggest that in flocks, whose antibody levels are high, no increased protection may be achieved by revaccination during lay and an adverse effect upon egg production and quality can be induced 
by the vaccine itself. Poor egg specific gravity, reduced shell thickness, misshapen eggs, pale shell pigmentation, watery albumen that leads to greatly reduced Haugh Unit (HU) values are a reflection of dysfunctional or damaged oviducts (Butcher \& Miles, 2001). Although the use of live and killed vaccines which promote a wide spectrum of antibody is suggested, however, the use of live vaccines on farms where laying birds are present should be avoided. Revaccination with mild IB virus vaccine during lay needs to be justified on the grounds that the optimum egg production is obtained in flocks where IB is not circulating or introduced, although the role of IBV in cases of egg production drop or poor eggshell quality is unknown (Ignjatovic et al., 2001).

\section{IB Antibody Titre Levels}

There were significant effects of initial vaccination treatment on IB antibody titre levels that measured at 4,6 , and 16 weeks of age. IB antibody titre was higher for A3 eyedrop than all peaks and control, but there were no different with A3 coarse and A3 water (Table 3). However, there were not significant effects of revaccination on IB antibody titre levels until 49 weeks of measurements. The titre levels of all groups increased significantly from 4 weeks to 16 weeks of age. The con-

Tabel 3. IB antiboby titres in 4-16 weeks of age of hens treated with initial vaccination

\begin{tabular}{lc}
\hline & IB antibody titres \\
\hline Control & $743 \pm 277^{\mathrm{c}}$ \\
VicS, eyedrop at day-old & $825 \pm 228^{\mathrm{c}}$ \\
VicS, coarse spray at day-old & $1,110 \pm 248^{\mathrm{bc}}$ \\
VicS, in water at day-old & $808 \pm 218^{\mathrm{c}}$ \\
A3, eyedrop at day-old & $2,015 \pm 445^{\mathrm{a}}$ \\
A3, coarse spray at day-old & $1,195 \pm 317^{\mathrm{abc}}$ \\
A3, in water at day-old & $1,756 \pm 429^{\mathrm{ab}}$ \\
\hline
\end{tabular}

Note: Means in the same column with different superscript differ significantly $(\mathrm{P}<0.05)$

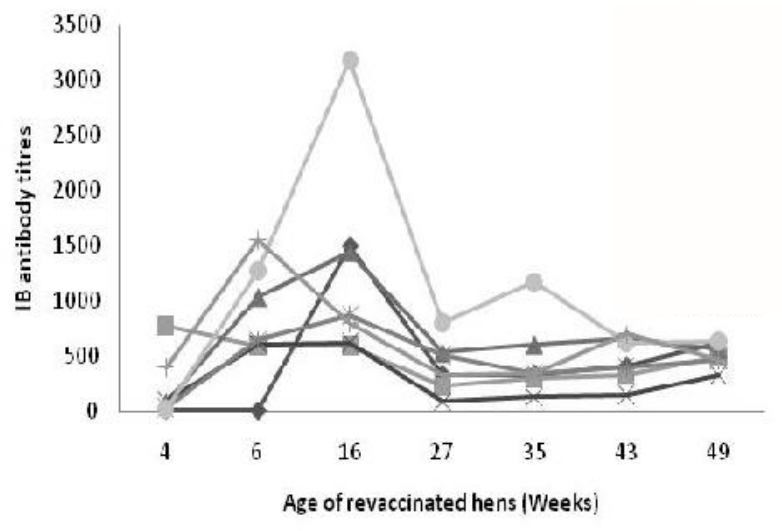

A trol group of birds remained negative for IB antibodies until they were vaccinated with VicS at 14 weeks of age (Figure 2).

Even though there was no different of IB antibody titre level between revaccinated regularly hens and not revaccinated hens, the titre levels of all groups increased significantly from 4 weeks to 16 weeks of age. The results indicated the increase in immune response following vaccination. The increase of antibody titres is an indication that the vaccination has been carried out carefully and correctly (Cook et al., 1999).

Since there is no appropriate drug therapy for controlling this disease, vaccination is still the main strategy for protecting chickens from IB virus infection (Lister, 2001). For the initial vaccination of breeders and layers, and also for broilers, both live and inactivated virus vaccines are applicable. However, at point of lay in breeders and layers inactivated oil-emulsion vaccines are used in many countries although live (attenuated) vaccines are used in poultry industry. Commercial mass application methods of IB vaccination include coarse spray, aerosol, and drinking water (Cavanagh \& Gelb Jr., 2008). It appears that good immunity can be achieved when vaccine is administered via a range of different routes, provided that each bird receives an adequate vaccine dose. Landman (2002) reported that protection provided by live and inactivated virus vaccination against challenge with the virulent nephropathogenic infectious bronchitis virus (NIBV) strain PA/Wolgemuth/98 was assessed. Even though, serum IBV enzyme-linked immunosorbent assay antibody geometric mean titers (GMTs) after vaccination with the combinations of live attenuated strains were low, ranging from 184 to 1354, and prior to NIBV challenge at $10 \mathrm{wk}$ of age.

Live IB vaccines are generally recognized as providing good initial protection against infection, but in trying to provide immunity throughout the laying period, revaccination of hens during lay is recommended. Continual use of live vaccines complicates diagnosis since no simple diagnostic tool can differentiate in a field from a vaccine strain (Ignjatovic \& Sapats, 2000). Studies of molecular epizootiology reveal a strong probability that vaccination may lead to the spread of a vac-

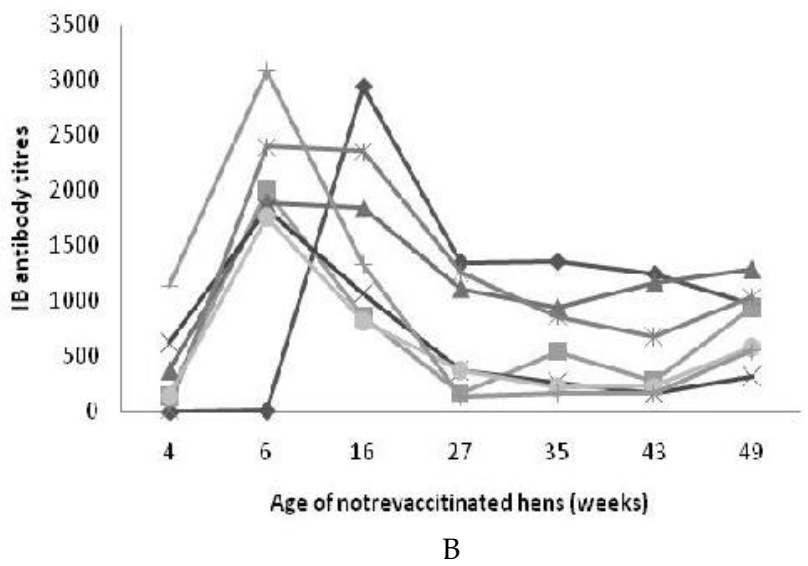

Figure 2. IB antibody titres of revaccinated hens regularly every 8 weeks (A) and not revaccinated hens during lay (B), control: - $\downarrow-$, Vics eye: -₫-, Vics spray: - $\mathbf{\Delta}-$, Vics water: -x-, A3 eye: -- 
cine virus, causing various disease manifestations and a confusing epizootiological situation in a poultry population (Farsang et al., 2002). Nephropathogenic infectious bronchitis (NIB) was diagnosed in 28 infectious bronchitis virus (IBV)-vaccinated commercial chicken flocks in Pennsylvania that show minimal respiratory disease signs in broilers, egg production and shell quality declined in layers (Ziegler et al., 2002). All vaccines such as VicS, A3, Steggles, Inghams, and others that have been used in poultry industry are considered to give good protection against several virulent, nephritis-inducing viruses of different sub-types. However, their safety and efficacy have been a matter of some controversy.

\section{CONCLUSION}

There was little advantage in regularly revaccinating laying hens for IB virus, since they have received appropriate initial vaccination.

\section{ACKNOWLEDGEMENT}

The support of Australian Egg Corporation Limited for this study is gratefully acknowledged and also we thank greatly Mrs. Wendy Ball for her laboratory assistance.

\section{REFERENCES}

Butcher, G. D. \& R. Miles. 2001. Infectious bronchitis and its effect on egg production and egg quality. http://www.afn. org/ poultry/flkman3.htm [15 September 2003]

Cavanagh, D. 2003. Severe cute respiratory syndrome vaccine development: Experiences of vaccination against avian infectious bronchitis coronavirus. Avian Phatol. 32: 567-582.

Cavanagh, D. \& J. Gelb Jr. 2008. Infectious Bronchitis. In: Y.M. Saif (Ed. in Chief), Diseases of Poultry. $12^{\text {th }}$ ed. Iowa State University Press, Ames. pp. 118-136.

Choulsalkar, K. K., J. R. Roberts, \& R. Reece. 2007. Comparative histopathology of two serotypes of infectious bronchi- tis virus (T and N1/88) in laying hens and cockerels. Poult. Sci. 86: 50-58

Cook, J. K . A. 2008. Coronaviridae. In: M. Pattison, P.F. McMullin, J.M. Bradbury \& D.J. Alexander (Eds.). Poultry Diseases. 6th ed. Saunders Elsevier, Philadelphia, Pennsylvania. pp. 340-349.

De Wit, J. J., K. A. Cook, \& H. M. J. F. van der Heijden. 2011. Infectious bronchitis virus variants: a review of the history, current situation and control measures. Avian Pathol. 40: 223-235.

De Wit, J. J., J. M. Swart, \& T. H. F. Fabri. 2010. The efficacy of infectious bronchitis virus vaccinations in the field: association between the $\alpha$-IBV IgM response, protection and vaccine application parameters. Avian Pathol. 39: 123-132.

Farsang, A., C. Ros, L. H. M. Renstrom, C. Baule, T. Soos, \& S. Belak. 2002. Molecular epizootiology of infectious bronchitis virus in Sweden indicating the involvement of a vaccine strain. Avian Pathol. 31: 229-236.

Ignjatovic, J. \& S. Sapats. 2000. Avian infectious bronchitis virus. Rev. Sci. Tech. Off. Int. Epizoot. 19: 493-503.

Ignjatovic, J., D. F.Ashton, R. Reece, P.Scott, \& P. Hooper. 2001. Pathogenicity of Australian strains of avian infectious bronchitis virus. J. Comp. Pathol. 125: 1-9.

Jackwood, M. K. D. A. Hilt, A. W. McCall, C. N. Polizzi, E. T. McKinley, \& S. M. Williams. 2009. Infectious bronchitis virus field vaccination coverage and persistence of Arkansas-type viruses in commercial broilers. Avian Dis.: 175183.

Landman, B. S, C. R. Pope, A. F. Ziegler, T. Swieczkowski, J. M. Callahan, S. Davison, \& J. Gelb Jr. 2002. Protection of chickens after live and inactivated virus vaccination against challenge with nephropathogenic infectious bronchitis virus PA/Wolgemuth/98. Avian Dis. 46: 938-944.

Lister, S. A. 2001. Infectious Bronchitis - A Significant World Problem. Antec International Ltd. http://www.antecint. co.uk./main/infectbr.htm [15 September 2003].

Roberts, J. R. 2004. Factors affecting eggs internal quality and egg shell quality in laying hens. J. Poul. Sci. 41: 161-177.

Ziegler, A. F., B. S. Landman, P. A. Dunn, A. Schneider, S. Davison, P. G. Miller, H. Lu, D. Weinstock, M. Salem, R. J. Eckroade, \& J. Gelb Jr. 2002. Nephropathogenic infectious bronchitis in Pennsylvania chickens 1997-2000. Avian Dis. 46: 847-858. 